Check for updates

Cite this: RSC Adv., 2019, 9, 31773

Received 15th August 2019

Accepted 20th September 2019

DOI: 10.1039/c9ra07527e

rsc.li/rsc-advances

\section{Synthesis and reactivity of 2-thionoester pyrroles: a route to 2 -formyl pyrroles $\uparrow$}

\author{
Min Joon Kim, Sophie M. Gaube, Michael H. R. Beh, Craig D. Smith \\ and Alison Thompson (D) *
}

2-Functionalised pyrroles exhibit considerable synthetic utility. Herein, the synthesis and reactivity of 2thionoester $(-\mathrm{C}(\mathrm{S}) \mathrm{OR})$ pyrroles is reported. 2-Thionoester pyrroles were synthesised using a Knorr-type approach from aliphatic starting materials. 2-Thionoester pyrroles were reduced to the corresponding 2formyl pyrroles, or the deuterated formyl variant, in one step using RANEY® nickel, thereby removing the need for the much-utilised hydrolysis/decarboxylation/formylation steps that are typically required to convert Knorr-type 2-carboxylate pyrroles into 2-formyl pyrroles. 2-Thionoester pyrroles proved tolerant of typical functional group interconversions for which the parent 2-carboxylate pyrroles have become known.
2-Formyl pyrroles are critical to the synthesis of (poly)pyrroles such as porphyrins and BODIPYs courtesy of their availability from widely used Knorr-type syntheses, and their robust and reliable reactivity. ${ }^{1}$ However, attempts to reduce the 2-carboxylate functionality of Knorr-type pyrroles with H-DIBAL are unfruitful, which is unsurprising considering the doublyvinylogus carbamate character of the ester (Fig. 1, top). Instead, transformation to 2 -formyl pyrroles typically entails hydrolysis of the 2-carboxylate functionality, ${ }^{2,3}$ followed by decarboxylation and finally formylation. ${ }^{4-7}$ Alternatively, reduction of the 2-carboxylate functionality to the corresponding alcohol, followed by oxidation back to the desired aldehyde, ${ }^{8}$ also provides the requisite 2 -formyl pyrrole. In addition to the inevitably poor atom economy that results from such circuitousness, these reactions can be low yielding and necessitate harsh conditions. The potential of utilising new reactivity at the 2-position of pyrroles opens new synthetic opportunities in pyrrole chemistry that build on traditional approaches. ${ }^{9}$ Herein, we report the one-step reduction of 2-thionoester pyrroles to provide 2-formyl pyrroles, and explore the stability of 2-thionoester pyrroles under conditions typically used for the synthetic manipulation of Knorr-type pyrroles.

2-Thionoester pyrroles, which bear the $-\mathrm{C}(\mathrm{S}) \mathrm{OR}$ functional group at the 2-position, have not been studied in detail despite the fact that thionoesters are more electrophilic compared to the corresponding "all-oxygen ester" functional groups $\left(-\mathrm{CO}_{2} \mathrm{R}\right) \cdot{ }^{10,11}$ In contrast, 2 -thioester pyrroles $(-\mathrm{C}(\mathrm{O}) \mathrm{SR})$ have been thoroughly evaluated as such species are common

Department of Chemistry, Dalhousie University, P. O. Box 1500o, Halifax, NS, B3H 4R2, Canada. E-mail: Alison.Thompson@dal.ca

$\dagger$ Electronic supplementary information (ESI) available: Experimental details including synthetic procedures and NMR spectra. See DOI: 10.1039/c9ra07527e secondary metabolites in marine bacteria and plants., ${ }^{9,12,13}$ In particular, we noticed a role for thiophilic reagents in the reduction of 2 -thioester pyrroles ${ }^{14-17}$ induced by RANEY ${ }^{\circledR}$ nickel. ${ }^{14,15,18}$

We thus explored the reactivity of 2-thionoester pyrroles with RANEY ${ }^{\circledR}$ nickel, taking advantage of the availability of RANEY ${ }^{\circledR}$ nickel as a slurry in water. $O$-Ethyl 2-thionoester pyrrole 1a, initially prepared via treatment of the corresponding 2-carboxylate pyrrole with Lawesson's reagent, ${ }^{9}$ was reacted with excess 2800 RANEY® nickel to provide the 2-formyl pyrrole 2a in $67 \%$ isolated yield (Table 1, entry 1). To commence the reaction, a slurry of RANEY® nickel in water and acetone was activated via heating at reflux temperature for an hour before 1a was added. Although the purpose of the activation step is unclear,

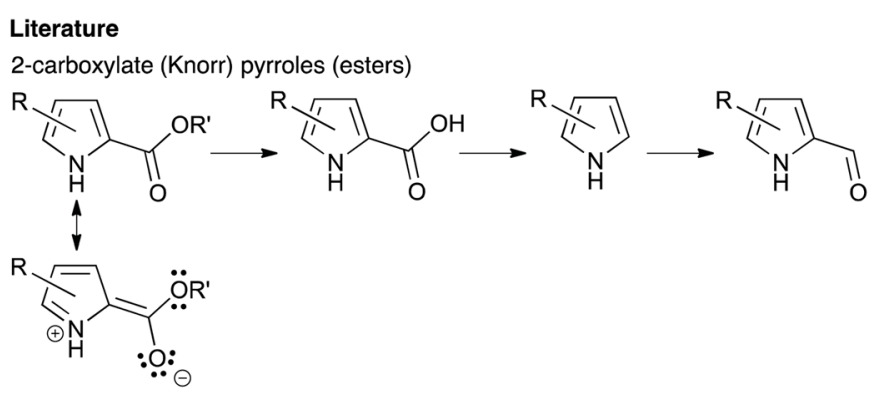

This work

2-thionoester pyrroles



Fig. 1 Conversion of Knorr-type pyrroles to 2-formyl pyrroles. 
Table 1 Reduction of 2-carboxylate pyrroles to 2-formyl pyrroles using RANEY® nickel

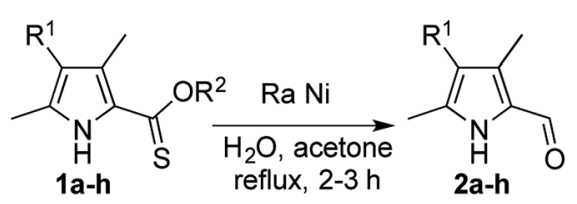

\begin{tabular}{lllll}
\hline Entry & Substrate & $\mathrm{R}^{1}$ & $\mathrm{R}^{2}$ & ${\text { Yield of } 2(\%)^{a}}^{a}$ \\
\hline 1 & $\mathbf{1 a}$ & $-\mathrm{H}$ & $\mathrm{Et}$ & 67 \\
2 & $\mathbf{1 b}$ & $-\mathrm{Me}$ & $\mathrm{Et}$ & 52 \\
3 & $\mathbf{1 c}$ & $-\mathrm{Et}$ & $\mathrm{Et}$ & 63 \\
4 & $\mathbf{1 d}$ & $-\mathrm{Ph}$ & $\mathrm{Et}$ & 45 \\
5 & $\mathbf{1 e}$ & $-\mathrm{C}(\mathrm{O}) \mathrm{CH}_{3}$ & $\mathrm{Et}$ & $44^{b}\left(46^{c}\right)$ \\
6 & $\mathbf{1 f}$ & $-\mathrm{Me}$ & $\mathrm{Bn}$ & $45^{d}$ \\
7 & $\mathbf{1 g}$ & $-\left(\mathrm{CH}_{2}\right)_{4} \mathrm{CH}_{3}$ & $\mathrm{Bn}$ & 70 \\
8 & $\mathbf{1 h}$ & $-\left(\mathrm{CH}_{2}\right)_{2} \mathrm{C}(\mathrm{O}) \mathrm{OCH}_{3}$ & $\mathrm{Bn}$ & 12
\end{tabular}

${ }^{a}$ Isolated yield. ${ }^{b} 15 \%$ starting material recovered. ${ }^{c}$ Deuterated $2 \mathrm{e}^{\prime}$ using RANEY ${ }^{\circledR}$ nickel in $\mathrm{D}_{2} \mathrm{O}$ slurry. ${ }^{d}$ Expected product is $\mathbf{2 b}$.

this procedure is documented alongside the success of W2 RANEY® nickel in the desulfurisation of a 2-thioester pyrrole. ${ }^{19}$ We found that this activation step was essential for success of our desired reduction using currently commercially available 2800 RANEY® nickel, which is different from W2 RANEY® nickel. After the starting material has been fully consumed, the reaction mixture was filtered through a short pad of silica to remove the spent RANEY® nickel and thus enable isolation of the desired aldehyde. Execution of the reaction under an atmosphere of hydrogen did not improve the yield, ${ }^{\mathbf{1 8 2 0 - 2 2}}$ supporting the synergy of the thiophilicity and hydride content of the RANEY® nickel, and we were unable to reduce the stoichiometry without significant detriment to yield (see ESI†). Similarly, dissolution of the substrate in acetone was key to success, as the use of other water-miscible solvents (methanol, ethanol, tetrahydrofuran and isopropanol), ${ }^{23}$ all previously reported as suitable for reactions involving RANEY® nickel, resulted only in isolation of starting material. Furthermore, treatment of 1a with nickel boride returned only starting material. ${ }^{24}$

Although yields were moderate (Table 1), the one-step desulfurative reduction of 2-thionoester pyrroles to 2-formyl pyrroles is more streamlined than the common hydrolysis/ decarboxylation/formylation route shown in Fig. 1. The onestep synthesis of 2-formyl pyrroles from $O$-ethyl 2-thionoester pyrroles in reasonable yield was successful for substrates bearing unsubstituted positions (1a, Table 1, entry 1) as well as those with alkyl (entries 2 and 3) and aryl (entry 4) substituents. Similarly, the incorporation of a conjugated keto-substituent was tolerated (entry 5). The reduction of $O$-benzyl 2-thionoester pyrroles was also successful (entries 6-9). Long-chain substituents were tolerated (entry 7), but incorporation of an alkyl ester functionality served to reduce the efficacy of the desired thionoester reduction using RANEY® nickel (entry 8).

Although a complete mechanism for desulfurisation by RANEY® nickel remains unclear, ${ }^{25,26}$ we explored a number of avenues to try to understand the atom efficiency of the reaction, as well as the source of the formyl hydrogen atom. First, although we did not attempt to dry the pyrophoric reductant, water from the commercially available RANEY® nickel slurry was manually removed by pipette. Acetone was then added, and the slurry shaken. After being allowed to settle, the liquid was removed once again. This process was repeated several times so as to produce a slurry of RANEY® nickel in wet acetone. The reaction of pyrrole 1e with this acetone-based slurry resulted in only trace amounts of 2 e suggesting that the water within the slurry is critical to the formation of the aldehyde. To investigate whether deuterium ${ }^{27,28}$ could be introduced into the 2-formyl moiety, a slurry of RANEY® nickel in $\mathrm{D}_{2} \mathrm{O}$ was prepared through removal/addition as above, with the added sonication step after each addition. The solvent removal/addition and sonicator wash cycle was repeated 10 times to ensure efficient exchange. Reaction of the deuterated slurry with pyrrole 1e, in acetone, resulted in formation of the deuterated aldehyde i.e. $\mathrm{R}-\mathrm{C}(\mathrm{O}) \mathrm{D}$, $2 \mathbf{e}^{\prime}$ in moderate yield (Table 1, entry 6). Interestingly, without the use of sonication a $3: 1$ mixture of the deuterated and undeuterated aldehydes was recovered, again indicating the critical role of the slurry water to the reductive capability of the RANEY® nickel.

The manner by which RANEY® nickel effects desulfurative reduction has been long debated. ${ }^{25,26,29}$ Assuming a radical mechanism, we used two radical clocks/traps in the hopes of intercepting radical intermediate species (Fig. 2). ${ }^{\mathbf{3 0 , 3 1}}$ However, in neither case was trapping observed with reduction of $\mathbf{1 a}$ serving to return the 2-formyl pyrrole 2a (50-60\% yield) no matter whether large excess of a cyclopropane were present or not. However, in light of the large excess of RANEY® nickel used, we maintain that a radical mechanism is most likely for the reduction. In contrast, reaction of $1 \mathrm{a}$ with RANEY® nickel in the presence of 50 eq. TEMPO resulted in the isolation of only 7\% 2a. However, no trapped products could be identified via either mass spectrometry or NMR spectroscopy. ${ }^{32,33}$

With the one-step reduction to form 2-formyl pyrroles in hand, we sought a practical synthesis of 2-thionoester pyrroles that did not entail thionation of 2-carboxylate pyrroles. We thus turned our attention to the preparation of 2-thionoester pyrroles from aliphatic materials, modelling the Knorr synthesis by incorporation of thionoester functionality. Reaction of potassium ethyl xanthogenate and chloroacetone, following modified literature methods, ${ }^{34,35}$ gave 3 (Scheme 1), and then extrusion of sulfur produced the desired acetothioacetate 4 . Treatment with sodium nitrite gave the oxime $\mathbf{5}$, which could be isolated and characterised although the typical procedure entailed treating the crude material with 2,4-pentanedione and zinc powder to provide $O$-ethyl 2-thionoester

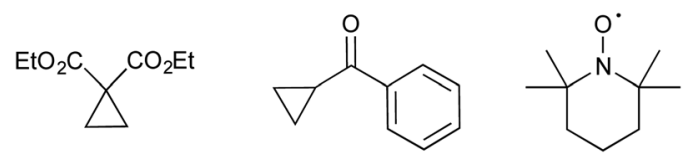

Fig. 2 Cyclopropane radical clocks and TEMPO. 
<smiles>CCOC(=O)C(=O)CC(=S)OCC</smiles>
$\mathrm{NaNO}_{2}(\mathrm{aq})$,<smiles>[R]c1c(C)[nH]c(C([X])OCC)c1C</smiles><smiles>CC(=O)CC(C)=O</smiles>

$\checkmark$

$\mathrm{X}=\mathrm{S}, \mathrm{R}=\mathrm{C}(\mathrm{O}) \mathrm{CH}_{3}, 1 \mathrm{e}, 30 \%$

$X=O, R=C(O) \mathrm{CH}_{3}, \mathbf{6}, 18 \%$

$X=S, R=H, 1 a, 13 \%$

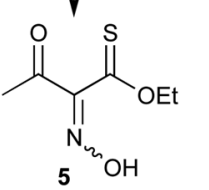

Scheme 1 Knorr-type synthesis of o-ethyl 2-thionoester pyrrole.

pyrrole 1e. As with traditional Knorr-type syntheses, ${ }^{36}$ byproducts accompanied the desired pyrrole: $\mathbf{6}$ is the ester $\left(-\mathrm{CO}_{2} \mathrm{R}\right)$ variant of $\mathbf{1 e}$; and $\mathbf{1 a}$ is produced as a consequence of deacylation. As such, the basic Knorr conditions were modified using various stoichiometries of sodium carbonate, tripotassium phosphate and sodium acetate salts to assert that the use of sodium carbonate resulted in the highest yield (33\%) of the desired 2-thionoester pyrrole 1e. Cognisant that a Knorr-type synthesis of 2-carboxylate pyrroles yields $30-60 \%$ of the desired product on the same scale, this synthetic approach to 2thionoester pyrroles is in keeping with the most prevalent of the routes to functionalised pyrroles. ${ }^{37,38}$ The corresponding benzyl thionoester pyrrole was synthesised following a similar approach, but originating with the reaction of $\mathrm{CS}_{2}$ with benzyl alcohol in the presence of potassium hydroxide to produce the required potassium $O$-benzyl carbonodithioate starting material.

In order to probe the utility of 2-thionoester pyrroles beyond their conversion to 2 -formyl pyrroles, we explored the potential of $1 \mathrm{e}$ as a substrate for the most common reactions that utilise 2-carboxylate pyrrole analogues. As shown in Scheme 2, treatment of 1e with borane cleanly reduced the acyl group to give the corresponding ethyl derivative 1c, no matter whether borane were generated in situ (Method A) or used as reagent (Method B). 2-Thionoester 1c mirrored the reactivity of 2carboxylate pyrroles in the preparation of dipyrrins, thereby providing 7. Similarly, treatment of 1e with base effected hydrolysis and decarboxylation to give $\mathbf{8}$, and treatment with acid resulted in deacylation to render 1a. However, reaction of pyrrole 1e with $\mathrm{CAN}$ or $\mathrm{Pb}(\mathrm{OAc})_{4}$ returned the corresponding ester $\left(-\mathrm{CO}_{2} \mathrm{R}\right)$ with no sign of the desired oxidation of the 5methyl group, clearly presenting a limitation as none of the desired 5-formyl species was produced.

In conclusion, an alternative route to 2-formyl pyrroles has been achieved via development of a modified Knorr procedure to produce 2-thionoester pyrroles, followed by the use of RANEY ${ }^{\circledR}$ nickel to promote reduction of the thionoester moiety to an aldehyde. The tolerance and utility of 2-thionoester pyrroles in reactions that are in widespread use within dipyrrin and porphyrin chemistry were investigated. Given the circuitousness nature of the synthesis of 2-formyl pyrroles of this genre and for these applications, the synthesis and use of 2thioester pyrroles is presented as a viable alternative to the specialised manipulation of traditional Knorr-type 2-carboxylate pyrroles.

\section{Experimental section}

\section{General information}

Anhydrous solvents, silica 40-63 $\mu \mathrm{m} 60 \AA$ and reagents were purchased and used as received. NMR spectra were obtained using 300 or $500 \mathrm{MHz}$ instruments using $\mathrm{CDCl}_{3}$ or DMSO as solvents and are reported in part per million (ppm). Internal solvents were referenced at $7.26 \mathrm{ppm}$ for ${ }^{1} \mathrm{H}$ and at $77.16 \mathrm{ppm}$ for ${ }^{13} \mathrm{C}$ when using $\mathrm{CDCl}_{3}$, and at $2.50 \mathrm{ppm}$ for ${ }^{1} \mathrm{H}$ when using DMSO- $\mathrm{d}_{6}$. Coupling constants $(J)$ are given in Hertz $(\mathrm{Hz})$. Mass spectra were obtained using a time-of-flight ion trap instrument

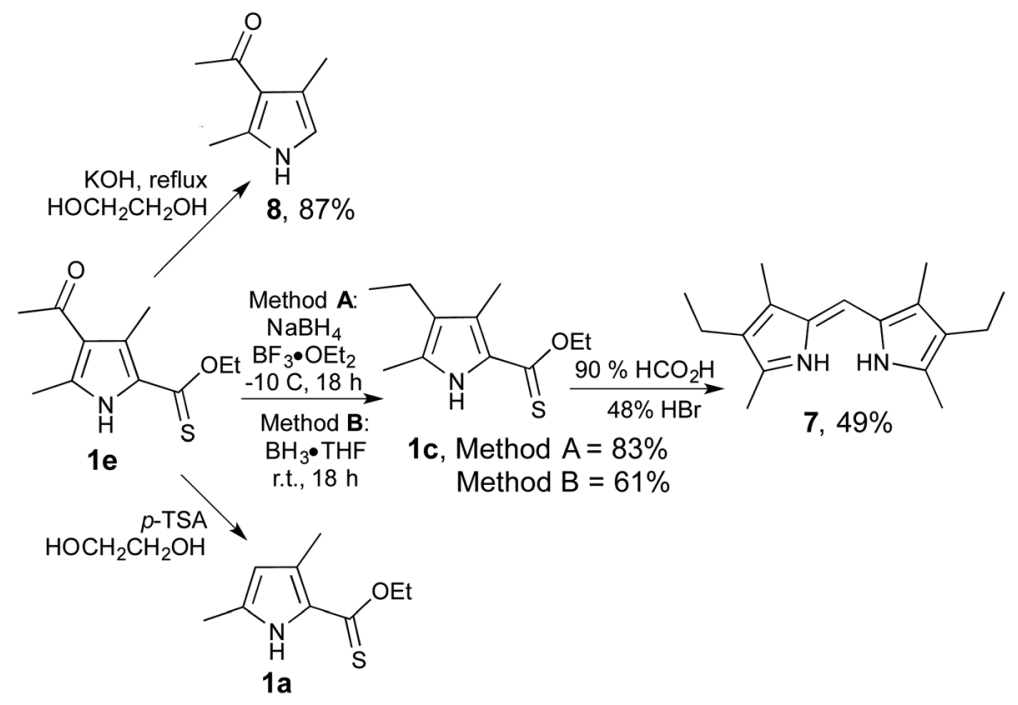

Scheme 2 Reactions of 2-thionoester pyrrole $1 \mathrm{e}$ 
operating in $\mathrm{ESI}^{+/-}$mode. Flash chromatography was performed using Silicycle ultra-pure silica (230-400 mm). Pyrroles $\mathbf{1 a}, \mathbf{1 b}, \mathbf{1 e}$, and $\mathbf{1 f}$ were prepared according to literature procedure involving Lawesson's reagent. ${ }^{9}$ Compound 3 was prepared according to the literature method. ${ }^{39}$ RANEY® nickel used was W. R. Grace Grade 2800 (CAS\# 7440-02-0), purchased in the form of a slurry in water with the nickel composition stated as equal to or greater than $89 \%$. Before each use, the bottle containing the RANEY® nickel slurry was thoroughly shaken before aliquots were drawn out quickly with a pipette in order to enable efficient transfer of the slurried material to a reaction flask.

\section{O-Ethyl 4-ethyl-3,5-dimethyl-1 $\mathrm{H}$-pyrrole-2-carbothioate (1c)}

According to the literature method, ${ }^{40}$ the title compound was obtained as a yellow solid (0.63 g, 60\%). Mp 66-68 ${ }^{\circ} \mathrm{C} ;{ }^{1} \mathrm{H}-\mathrm{NMR}$ $\left(500 \mathrm{MHz}, \mathrm{CDCl}_{3}\right): \delta 9.08($ broad s, $1 \mathrm{H}), 4.66(\mathrm{q}, 2 \mathrm{H}, J=7.0 \mathrm{~Hz})$, $2.36(\mathrm{q}, 2 \mathrm{H}, J=7.5 \mathrm{~Hz}), 2.27(\mathrm{~s}, 3 \mathrm{H}), 2.21(\mathrm{~s}, 3 \mathrm{H}), 1.46(\mathrm{t}, 3 \mathrm{H}, J=$ $7.0 \mathrm{~Hz}$ ), 1.04 (t, 3H, $J=7.5 \mathrm{~Hz}) ;{ }^{13} \mathrm{C} \mathrm{NMR} \mathrm{(125} \mathrm{MHz,} \mathrm{CDCl}_{3}$ ): $\delta 199.5,134.2,128.7,126.0,66.5,17.2,15.4,14.3,12.0,11.9$, one carbon signal missing; HRMS-ESI $(\mathrm{m} / \mathrm{z}):[\mathrm{M}+\mathrm{Na}]^{+}$calculated for $\mathrm{C}_{11} \mathrm{H}_{17} \mathrm{NNaOS}, 234.0923$; found 234.0931.

\section{O-Ethyl 3,5-dimethyl-4-phenyl-1H-pyrrole-2-carbothioate (1d)}

According to the literature method, ${ }^{40}$ the title compound was obtained as a yellow solid (0.76 g, 39\%). Mp 89-92 ${ }^{\circ} \mathrm{C} ;{ }^{1} \mathrm{H}-\mathrm{NMR}$ (300 MHz, $\left.\mathrm{CDCl}_{3}\right): \delta 9.31$ (broad s, $\left.1 \mathrm{H}\right), 7.39-7.45(\mathrm{~m}, 2 \mathrm{H}), 7.29-$ $7.34(\mathrm{~m}, 1 \mathrm{H}), 7.22-7.25(\mathrm{~m}, 2 \mathrm{H}), 4.71(\mathrm{q}, 2 \mathrm{H}, J=6.9 \mathrm{~Hz}), 2.30(\mathrm{~s}$, $3 \mathrm{H}), 2.26(\mathrm{~s}, 3 \mathrm{H}), 1.49$ (t, 3H, $J=6.9 \mathrm{~Hz}) ;{ }^{13} \mathrm{C}$ NMR $(125 \mathrm{MHz}$, $\left.\mathrm{CDCl}_{3}\right): \delta 200.0,134.5,134.3,130.2,129.0,128.4,126.6,124.8$, $66.8,14.3,12.9,12.5$, one carbon signal missing; HRMS-ESI $(\mathrm{m} /$ $z):[\mathrm{M}+\mathrm{Na}]^{+}$calculated for $\mathrm{C}_{15} \mathrm{H}_{17} \mathrm{NNaOS}, 282.0923$; found 282.0923 .

\section{$O$-Benzyl 3,5-dimethyl-4-pentyl-1 $H$-pyrrole-2-carbothioate (1g)}

According to the literature method, ${ }^{\mathbf{4 0}}$ the title compound was obtained as a yellow oil $(0.53 \mathrm{~g}, 50 \%) .{ }^{1} \mathrm{H}-\mathrm{NMR}(300 \mathrm{MHz}$, $\left.\mathrm{CDCl}_{3}\right): \delta 9.13($ broad s, $1 \mathrm{H}), 7.35-7.49(\mathrm{~m}, 5 \mathrm{H}), 5.70(\mathrm{~s}, 2 \mathrm{H}), 2.34$ $(\mathrm{t}, 2 \mathrm{H}, J=7.2 \mathrm{~Hz}), 2.24(\mathrm{~s}, 3 \mathrm{H}), 2.22(\mathrm{~s}, 3 \mathrm{H}), 1.42$ (quin., $2 \mathrm{H}, J=$ $7.2 \mathrm{~Hz}), 1.28-1.35(\mathrm{~m}, 4 \mathrm{H}), 0.91$ (t, 3H, $J=7.2 \mathrm{~Hz}) ;{ }^{13} \mathrm{C} \mathrm{NMR}(125$ $\left.\mathrm{MHz}, \mathrm{CDCl}_{3}\right): \delta 198.7,136.2,135.0,129.1,128.6,128.4,128.2$, 127.0, 124.7, 72.0, 31.7, 30.5, 23.9, 22.7, 14.2, 12.4, 12.0; HRMSESI $(\mathrm{m} / z):[\mathrm{M}+\mathrm{Na}]^{+}$calculated for $\mathrm{C}_{19} \mathrm{H}_{25} \mathrm{NNaOS}$, 338.1549; found 338.1545 .

\section{O-Benzyl 3,5-dimethyl-4-methylpropionic- $1 \mathrm{H}$-pyrrole-2- carbothioate (1h)}

According to the literature method, ${ }^{40}$ the title compound was obtained as a yellow solid (0.45 g, 43\%). Mp 98-100 ${ }^{\circ} \mathrm{C} ;{ }^{1} \mathrm{H}-\mathrm{NMR}$ $\left(500 \mathrm{MHz}, \mathrm{CDCl}_{3}\right): \delta 9.11$ (broad s, $\left.1 \mathrm{H}\right), 7.33-7.45(\mathrm{~m}, 5 \mathrm{H}), 5.67$ (s, 2H), $3.65(\mathrm{~s}, 3 \mathrm{H}), 2.69(\mathrm{t}, 2 \mathrm{H}, J=7.5 \mathrm{~Hz}), 2.41(\mathrm{t}, 2 \mathrm{H}, J=7.5$ $\mathrm{Hz}), 2.23(\mathrm{~s}, 3 \mathrm{H}), 2.23(\mathrm{~s}, 3 \mathrm{H}) ;{ }^{13} \mathrm{C} \mathrm{NMR}\left(125 \mathrm{MHz}, \mathrm{CDCl}_{3}\right)$ : $\delta 198.9,173.4,136.1,135.0,128.6,128.4,128.3,126.1,122.2$, 72.2 , 51.7, 34.8, 19.5, 12.3, 11.9, one carbon signal missing; HRMS-ESI $(\mathrm{m} / \mathrm{z}):[\mathrm{M}+\mathrm{Na}]^{+}$calculated for $\mathrm{C}_{18} \mathrm{H}_{21} \mathrm{NNaO}_{3} \mathrm{~S}$, 354.1134; found 354.1127.
General procedure for synthesising 2-formyl pyrroles from 2thionoester pyrroles (GP1)

Slurried RANEY® nickel ( $2 \mathrm{~mL}$ containing water and RANEY® nickel) was suspended in acetone, and the mixture was heated at reflux temperature for 1 hour. 2-Thionoester pyrrole 1 (0.47 $\mathrm{mmol})$ was dissolved in acetone $(10 \mathrm{~mL})$, and the resulting solution was added to the reaction mixture containing RANEY® nickel in acetone held at reflux temperature. The reaction mixture was heated at reflux temperature for 2 hours, with stirring under nitrogen gas. Analysis using thin layer chromatography showed the complete consumption of starting material and the appearance of the product at lower $R_{\mathrm{f}}$. The reaction mixture was allowed to cool to room temperature and then filtered through a short pad of silica, washing with acetone (500 $\mathrm{mL}$ ). The filtrate was concentrated under vacuum, diluted with ethyl acetate and washed with brine. The organic layer was then dried using anhydrous sodium sulfate, and the solvent was removed through use of a rotary evaporator to yield a dark greenish brown solid. The crude product was purified via column chromatography over silica, eluting with $40 \%$ ethyl acetate/hexanes.

\section{General procedure for radical studies (GP2)}

Following GP1, the radical clock or TEMPO was added along with 2-thionoester pyrrole 1a. Each reaction was run in parallel with a reference reaction prepared by GP1 using the same batch of RANEY® nickel. Cyclopropyl phenyl ketone: 500 equivalencies of the radical clock were added with 1a, and the product 2a was isolated in 55\% (in absence of a radical clock: 53\%). Diethyl cyclopropane-1,1-dicarboxylate: 200 equivalencies of the radical clock were added with $\mathbf{1 a}$, and the product $\mathbf{2 a}$ was isolated in 64\% (in absence of a radical clock: 58\%). TEMPO: 50 equivalencies of TEMPO were added with 1a, and the product $2 \mathbf{a}$ was isolated in 7\% (in absence of a radical trap: 37\%).

\section{2-Formyl-3,5-dimethylpyrrole (2a)}

Following GP1, the title compound was obtained as a beige solid (67\%). Mp 87-88 ${ }^{\circ} \mathrm{C}$; ${ }^{1} \mathrm{H}-\mathrm{NMR}\left(300 \mathrm{MHz}, \mathrm{CDCl}_{3}\right): \delta 10.16$ (broad s, 1H), $9.43(\mathrm{~s}, 1 \mathrm{H}), 5.82(\mathrm{~m}, 1 \mathrm{H}), 2.29$ (s, 3H), $2.27(\mathrm{~s}, 3 \mathrm{H})$; ${ }^{13} \mathrm{C}$ NMR $\left(125 \mathrm{MHz}, \mathrm{CDCl}_{3}\right): \delta 176.0,138.7,134.9,128.9,112.1$, 13.3, 10.7; HRMS-ESI $(\mathrm{m} / \mathrm{z}):[\mathrm{M}+\mathrm{Na}]^{+}$calculated for $\mathrm{C}_{7} \mathrm{H}_{9} \mathrm{NNaO}$, 146.0576; found 146.0576 .

\section{2-Formyl-3,4,5-trimethylpyrrole (2b) from $1 \mathrm{~b}$}

Following GP1, the title compound was obtained as a beige solid (52\%). Mp 142-145 ${ }^{\circ} \mathrm{C} ;{ }^{1} \mathrm{H}-\mathrm{NMR}\left(300 \mathrm{MHz}, \mathrm{CDCl}_{3}\right): \delta 9.99$ (broad s, 1H), $9.44(\mathrm{~s}, 1 \mathrm{H}), 2.24(\mathrm{~s}, 6 \mathrm{H}), 1.91(\mathrm{~s}, 3 \mathrm{H}) ;{ }^{13} \mathrm{C} \mathrm{NMR}$ $\left(125 \mathrm{MHz}, \mathrm{CDCl}_{3}\right): \delta 175.6,136.2,132.9,127.9,118.3,11.7,9.0$, 8.5; HRMS-ESI $(\mathrm{m} / \mathrm{z}):[\mathrm{M}+\mathrm{Na}]^{+}$calculated for $\mathrm{C}_{8} \mathrm{H}_{11} \mathrm{NNaO}$, 160.0733; found 160.0731 .

\section{4-Ethyl-2-formyl-3,5-dimethylpyrrole (2c)}

Following GP1, the title compound was obtained as a beige solid (63\%). Mp 98-100 ${ }^{\circ} \mathrm{C} ;{ }^{1} \mathrm{H}-\mathrm{NMR}\left(300 \mathrm{MHz}, \mathrm{CDCl}_{3}\right.$ ): $\delta 10.03$ (broad s, 1H), 9.45 (s, 1H), 2.38 (q, 2H, $J=7.5 \mathrm{~Hz}), 2.27$ (s, 3H), 
$2.26(\mathrm{~s}, 3 \mathrm{H}), 1.06(\mathrm{t}, 3 \mathrm{H}, J=7.5 \mathrm{~Hz}) ;{ }^{13} \mathrm{C} \mathrm{NMR}\left(125 \mathrm{MHz}, \mathrm{CDCl}_{3}\right)$ : $\delta 175.8,136.0,132.4,128.1,125.1,17.2$, 15.3, 11.7, 9.0; HRMSESI $(m / z):[\mathrm{M}+\mathrm{Na}]^{+}$calculated for $\mathrm{C}_{9} \mathrm{H}_{13} \mathrm{NNaO}, 174.0889$; found 174.0889 .

\section{2-Formyl-3,5,-dimethyl-4-phenylpyrrole (2d)}

Following GP1, the title compound was obtained as a beige solid (45\%). Mp 148-150 ${ }^{\circ} \mathrm{C} ;{ }^{1} \mathrm{H}-\mathrm{NMR}\left(300 \mathrm{MHz}, \mathrm{DMSO}-\mathrm{d}_{6}\right): \delta 11.77$ (br s, 1H), $9.56(\mathrm{~s}, 1 \mathrm{H}), 7.39-7.44(\mathrm{t}, 2 \mathrm{H}), 7.25-7.31(\mathrm{~m}, 3 \mathrm{H}), 2.25$ $(\mathrm{s}, 3 \mathrm{H}), 2.21(\mathrm{~s}, 3 \mathrm{H}) ;{ }^{13} \mathrm{C} \mathrm{NMR}\left(125 \mathrm{MHz} \mathrm{CDCl}_{3}\right): \delta 176.6,135.6$, 134.3, 131.7, 130.0, 128.5, 128.4, 126.7, 125.6, 12.4, 9.6; HRMSESI $(m / z):[\mathrm{M}+\mathrm{Na}]^{+}$calculated for $\mathrm{C}_{13} \mathrm{H}_{13} \mathrm{NNaO}, 222.0889$; found 222.0887 .

\section{4-Acetyl-2-formyl-3,5-dimethylpyrrole (2e)}

Following GP1, the title was compound was prepared as a beige solid (44\%). Mp 168-170 ${ }^{\circ} \mathrm{C} ;{ }^{1} \mathrm{H}-\mathrm{NMR}\left(300 \mathrm{MHz}, \mathrm{CDCl}_{3}\right): \delta 9.89$ (br s, 1H), $9.65(\mathrm{~s}, 1 \mathrm{H}), 2.58(\mathrm{~s}, 3 \mathrm{H}), 2.57(\mathrm{~s}, 3 \mathrm{H}), 2.46(\mathrm{~s}, 3 \mathrm{H}) ;{ }^{13} \mathrm{C}$ NMR (125 MHz, $\left.\mathrm{CDCl}_{3}\right): \delta$ 195.0, 177.7, 142.6, 134.2, 128.4, 123.9, 31.4, 15.4, 11.5; HRMS-ESI $(\mathrm{m} / \mathrm{z}):[\mathrm{M}+\mathrm{Na}]^{+}$calculated for $\mathrm{C}_{9} \mathrm{H}_{11} \mathrm{NNaO}_{2}, 188.0682$; found 188.0681.

\section{4-Acetyl-2-formyl-d-3,5-dimethylpyrrole (2e')}

To a slurry of RANEY® nickel $(2 \mathrm{~mL}$ containing water and RANEY® nickel), deuterium oxide ( $5 \mathrm{~mL}$ portion) was added. The reaction vessel was stirred and sonicated at room temperature for 30 seconds, and the solvent was decanted. The exchange/wash cycle was repeated 10 times. After a final wash, deuterium oxide $(2 \mathrm{~mL})$ and acetone $(10 \mathrm{~mL})$ were added. GP1 was followed to obtain the title compound as a beige solid (46\%). Mp ${ }^{1} \mathrm{H}-\mathrm{NMR}\left(300 \mathrm{MHz}, \mathrm{CDCl}_{3}\right.$ ): $\delta 9.69$ (br s, $\left.1 \mathrm{H}\right), 2.58$ (s, $3 \mathrm{H}), 2.57$ (s, 3H), 2.47 (s, 3H); ${ }^{13} \mathrm{C}$ NMR (125 $\mathrm{MHz}, \mathrm{CDCl}_{3}$ ): $\delta$ 195.0, $177.4(\mathrm{t}), 142.6,134.2,128.3,123.9,31.4,15.5,11.6$; HRMS-ESI $(\mathrm{m} / \mathrm{z}):[\mathrm{M}+\mathrm{Na}]^{+}$calculated for $\mathrm{C}_{9} \mathrm{H}_{10} \mathrm{DNNaO}_{2}$, 189.0745; found 189.0736 .

\section{2-Formyl-3,5-dimethylpyrrole (2b) from 1f}

Following GP1, the title compound was prepared $(45 \%) .{ }^{1} \mathrm{H}$ NMR (300 MHz, $\mathrm{CDCl}_{3}$ ): $\delta 9.86$ (broad s, 1H), $9.42(\mathrm{~s}, 1 \mathrm{H}), 2.23$ $(\mathrm{s}, 6 \mathrm{H}), 1.91(\mathrm{~s}, 3 \mathrm{H})$ matching the data given above for this compound.

\section{2-Formyl-3,5-dimethyl-4-pentylpyrrole (2g)}

Following GP1, the title compound was obtained as a beige solid (70\%). Mp 70-71 ${ }^{\circ} \mathrm{C} ;{ }^{1} \mathrm{H}-\mathrm{NMR}\left(300 \mathrm{MHz}, \mathrm{CDCl}_{3}\right.$ ): $\delta 9.87$ (br s, $1 \mathrm{H}), 9.47(\mathrm{~s}, 1 \mathrm{H}), 2.37(\mathrm{t}, 2 \mathrm{H}, J=7.5 \mathrm{~Hz}), 2.28(\mathrm{~s}, 3 \mathrm{H}), 2.27(\mathrm{~s}$, $3 \mathrm{H}), 1.45$ (quin., $2 \mathrm{H}, J=7.5 \mathrm{~Hz}), 1.28-1.38(\mathrm{~m}, 4 \mathrm{H}), 0.92(\mathrm{t}, 3 \mathrm{H}, J$ $=7.0 \mathrm{~Hz}) ;{ }^{13} \mathrm{C} \mathrm{NMR}\left(125 \mathrm{MHz}, \mathrm{CDCl}_{3}\right): \delta 175.8,135.6,132.3$, 128.0, 123.6, 31.8, 30.4, 23.9, 22.7, 14.2, 11.8, 9.0; HRMS-ESI $(\mathrm{m} /$ $z):[\mathrm{M}+\mathrm{Na}]^{+}$calculated for $\mathrm{C}_{12} \mathrm{H}_{19} \mathrm{NNaO}, 216.1359$; found 216.1362 .

\section{2-Formyl-3,5-dimethyl-4-methylpropionic pyrrole (2h)}

Following GP1, the title was compound was obtained as a beige solid (12\%). Mp 128-129 ${ }^{\circ} \mathrm{C} ;{ }^{1} \mathrm{H}-\mathrm{NMR}\left(500 \mathrm{MHz}, \mathrm{CDCl}_{3}\right): \delta 9.82$ (br s, 1H), $9.45(\mathrm{~s}, 1 \mathrm{H}), 3.66(\mathrm{~s}, 3 \mathrm{H}), 2.72(\mathrm{t}, 2 \mathrm{H}, J=7.0 \mathrm{~Hz}), 2.44$ $(\mathrm{t}, 2 \mathrm{H}, J=7.5 \mathrm{~Hz}), 2.27(\mathrm{~s}, 3 \mathrm{H}), 2.26(\mathrm{~s}, 3 \mathrm{H}) ;{ }^{13} \mathrm{C} \mathrm{NMR}(125 \mathrm{MHz}$, $\left.\mathrm{CDCl}_{3}\right): \delta 176.0,173.4,135.9,132.3,128.1,121.1,51.8,34.7$, 19.4, 11.7, 8.9; HRMS-ESI $(\mathrm{m} / \mathrm{z}):[\mathrm{M}+\mathrm{Na}]^{+}$calculated for $\mathrm{C}_{11} \mathrm{H}_{15} \mathrm{NNaO}_{3}, 232.0944$; found 232.0946.

\section{$O$-Ethyl acetothioacetate (4)}

The title compound was synthesised following a modified literature procedure. ${ }^{34}$ A solution of $S$-acetonyl $O$-ethyl dithiocarbonate $3^{39}(31.4 \mathrm{~g}, 176 \mathrm{mmol})$ in anhydrous $\mathrm{Et}_{2} \mathrm{O}(70 \mathrm{~mL})$ was added drop-wise over 20 minutes to a suspension of $\mathrm{NaH}$ $(60 \%$ in oil, $10.7 \mathrm{~g}, 268 \mathrm{mmol})$ in anhydrous $\mathrm{Et}_{2} \mathrm{O}(350 \mathrm{~mL})$ at $10{ }^{\circ} \mathrm{C}$, with stirring under nitrogen. After 10 minutes, the mixture was poured into aqueous $\mathrm{K}_{2} \mathrm{HPO}_{4}$ solution $(0.91 \mathrm{M}, 390$ $\mathrm{mL}$ ) and stirred. The ethereal layer was separated and the aqueous layer was extracted with $\mathrm{Et}_{2} \mathrm{O}(3 \times 200 \mathrm{~mL})$. The combined organic extracts were washed with brine $(300 \mathrm{~mL})$, dried over anhydrous $\mathrm{MgSO}_{4}$ and concentrated in vacuo. The crude product was purified via fractional vacuum distillation (heated at $140-150{ }^{\circ} \mathrm{C}$ ), using a water-fed aspirator $(\sim 25-60$ $\mathrm{mmHg}$ ), and the desired product was collected at $84{ }^{\circ} \mathrm{C}$ as a yellow liquid $(14.1 \mathrm{~g}, 55 \%)$. The product was present in both enol and keto forms with an approximate $3: 1$ enol-keto ratio, according to the ${ }^{1} \mathrm{H}$ NMR spectrum. ${ }^{1} \mathrm{H}-\mathrm{NMR}\left(300 \mathrm{MHz}, \mathrm{CDCl}_{3}\right)$ : $\delta 13.75(\mathrm{~s}, 1 \mathrm{H}), 5.67(\mathrm{~s}, 1 \mathrm{H}), 4.54(\mathrm{q}, J=7.1 \mathrm{~Hz}, 0.7 \mathrm{H}), 4.47(\mathrm{q}, J=$ $7.1 \mathrm{~Hz}, 2 \mathrm{H}), 3.89(\mathrm{~s}, 0.7 \mathrm{H}), 2.26(\mathrm{~s}, 1 \mathrm{H}), 2.03(\mathrm{~s}, 3 \mathrm{H}), 1.41(\mathrm{t}, J=$ $7.1 \mathrm{~Hz}, 1 \mathrm{H}), 1.38(\mathrm{t}, J=7.1 \mathrm{~Hz}, 3 \mathrm{H})$, in accordance with literature. ${ }^{34}$ However, the literature ${ }^{34}$ reports a $4: 1$ enol-keto ratio.

\section{O-Ethyl 2-oximinoacetothioacetate (5)}

The title compound was synthesised following a modified literature procedure. ${ }^{\mathbf{4 1}}$ The resulting product mixture was poured into distilled water $(25 \mathrm{~mL})$ and extracted into $\mathrm{CH}_{2} \mathrm{Cl}_{2}$ (3 $\times 10 \mathrm{~mL}$ ). The combined organic fractions were washed with saturated $\mathrm{NaHCO}_{3}$, dried over anhydrous sodium sulfate and concentrated in vacuo to yield the product as a bright yellow solid (277 mg, 23\%). Mp 75-77 ${ }^{\circ} \mathrm{C} ;{ }^{1} \mathrm{H}-\mathrm{NMR}\left(300 \mathrm{MHz}, \mathrm{CDCl}_{3}\right.$ ): $\delta 8.13(\mathrm{~s}, 1 \mathrm{H}), 4.66(\mathrm{q}, J=7.1 \mathrm{~Hz}, 2 \mathrm{H}), 2.42(\mathrm{~s}, 3 \mathrm{H}), 1.45(\mathrm{t}, J=$ $7.1 \mathrm{~Hz}, 3 \mathrm{H}) ;{ }^{13} \mathrm{C} \mathrm{NMR}\left(125 \mathrm{MHz}, \mathrm{CDCl}_{3}\right): \delta 204.6,193.5,155.0$, 68.5, 26.0, 13.6; HRMS-ESI $(\mathrm{m} / \mathrm{z}):[\mathrm{M}+\mathrm{Na}]^{+}$calculated for $\mathrm{C}_{6}{ }^{-}$ $\mathrm{H}_{9} \mathrm{NO}_{3} \mathrm{SNa}, 198.0195$; found 198.0189 .

\section{O-Ethyl 4-acetyl-3,5-dimethyl-1H-pyrrole-2-carbothioate (1e)}

The title compound was synthesised following a modified literature procedure typically used for Knorr-type synthesis of 2carboxylate pyrroles. ${ }^{41}$ A solution of sodium nitrite $(530 \mathrm{mg}, 7.67$ $\mathrm{mmol})$ in distilled water $(1.9 \mathrm{~mL})$ was added drop-wise to a solution of $O$-ethyl acetothioacetate $(4)(1.02 \mathrm{~g}, 6.98 \mathrm{mmol})$ in $\mathrm{AcOH}(1.6 \mathrm{~mL})$ at $0{ }^{\circ} \mathrm{C}$. The reaction mixture was stirred at room temperature and monitored via thin layer chromatography until the starting material was consumed. After 45 minutes, the resulting mixture containing crude $O$-ethyl 2-oximinoacetothioacetate (5) was transferred to a dropping funnel and added drop-wise to a slurry of 2,4-pentanedione $(0.71 \mathrm{~mL}, 6.98 \mathrm{mmol})$, $\mathrm{Na}_{2} \mathrm{CO}_{3}(1.63 \mathrm{~g}, 15.3 \mathrm{mmol})$ and $\mathrm{AcOH}(10 \mathrm{~mL})$. At the same time, $\mathrm{Zn}$ dust $(0.958 \mathrm{~g}, 14.6 \mathrm{mmol})$ was slowly added to the 
slurry. The rate of addition and an ice-bath were used to keep the temperature below $30{ }^{\circ} \mathrm{C}$. After the addition was complete, the reaction mixture was stirred at room temperature and monitored via thin layer chromatography. After 30 minutes the resulting mixture was poured into distilled water $(150 \mathrm{~mL})$ and then filtered through Celite, washing with $\mathrm{CH}_{2} \mathrm{Cl}_{2}$ until the washings were colorless. ${ }^{\mathbf{4 0}}$ The filtrate was extracted with $\mathrm{CH}_{2} \mathrm{Cl}_{2}(3 \times 100 \mathrm{~mL})$. The combined organic fractions were washed with saturated $\mathrm{NaHCO}_{3}(150 \mathrm{~mL})$ and brine $(150 \mathrm{~mL})$, then dried over anhydrous $\mathrm{Na}_{2} \mathrm{SO}_{4}$ and the solvent evaporated in vacuo. The resulting residue was purified via column chromatography on silica, eluting with a gradient of 5-20\% EtOAc/ hexanes, yielding the desired product as a yellow solid $(0.53 \mathrm{~g}$, 33\%). Mp 109-111 ${ }^{\circ} \mathrm{C} ;{ }^{1} \mathrm{H}-\mathrm{NMR}\left(500 \mathrm{MHz}, \mathrm{CDCl}_{3}\right.$ ): $\delta 9.41$ (br s, $1 \mathrm{H}), 4.68(\mathrm{q}, J=7.1 \mathrm{~Hz}, 2 \mathrm{H}), 2.58(\mathrm{~s}, 3 \mathrm{H}), 2.52(\mathrm{~s}, 3 \mathrm{H}), 2.45(\mathrm{~s}$, $3 \mathrm{H}), 1.49(\mathrm{t}, J=7.1 \mathrm{~Hz}, 3 \mathrm{H})$, in accordance with literature. ${ }^{9}$

\section{3-Acetyl-2,4-dimethyl-1H-pyrrole (8) from 1e}

To a solution of ground $\mathrm{KOH}(252 \mathrm{mg}, 4.50 \mathrm{mmol})$ in ethylene glycol $(1.6 \mathrm{~mL})$ was added $1 \mathrm{e}(507 \mathrm{mg}, 2.25 \mathrm{mmol})$. The reaction mixture was heated at $160{ }^{\circ} \mathrm{C}$, with stirring, for 1 hour, monitoring via thin layer chromatography (40\% EtOAc/hexanes). Water $(5 \mathrm{~mL})$ was then added and the mixture was extracted into $\mathrm{CH}_{2} \mathrm{Cl}_{2}(3 \times 5 \mathrm{~mL})$. The combined organic layers were dried over anhydrous $\mathrm{Na}_{2} \mathrm{SO}_{4}$ and concentrated in vacuo to yield the desired product as an off-white solid (269 mg, 87\%). ${ }^{1} \mathrm{H}-\mathrm{NMR}$ $\left(500 \mathrm{MHz}, \mathrm{CDCl}_{3}\right): \delta 7.93$ (br s, 1H), $6.36(\mathrm{~s}, 1 \mathrm{H}), 2.50(\mathrm{~s}, 3 \mathrm{H})$, $2.42(\mathrm{~s}, 3 \mathrm{H}), 2.27(\mathrm{~s}, 3 \mathrm{H})$, in accordance with literature. ${ }^{41}$

\section{O-Ethyl 4-ethyl-3,5-dimethyl-1 $\mathrm{H}$-pyrrole-2-carbothioate (1c) from $1 e$}

Method 1. To a cooled solution $\left(-10{ }^{\circ} \mathrm{C}\right.$ ice per salt $)$ of $1 \mathrm{e}$ (496 mg, $2.20 \mathrm{mmol}$ ) in THF (4 mL) was added $\mathrm{NaBH}_{4}(184 \mathrm{mg}$, $4.40 \mathrm{mmol})$, and then $\mathrm{BF}_{3} \cdot \mathrm{OEt}_{2}(750 \mu \mathrm{L})$. The resulting mixture was stirred for 50 minutes at $-10{ }^{\circ} \mathrm{C}$, monitoring using TLC (20\% EtOAc/hexanes). $0.5 \mathrm{M} \mathrm{HCl}(5 \mathrm{~mL})$ was added at $0{ }^{\circ} \mathrm{C}$ to quench the reaction. Water $(10 \mathrm{~mL})$ was added and the mixture was extracted into $\mathrm{Et}_{2} \mathrm{O}(3 \times 10 \mathrm{~mL})$. The combined organic fractions were washed with brine $(15 \mathrm{~mL})$, dried over anhydrous $\mathrm{Na}_{2} \mathrm{SO}_{4}$ and concentrated in vacuo. The crude mixture was purified via column chromatography on silica, eluting with $5 \%$ EtOAc/hexanes to yield the desired product as a crystalline yellow solid (388 mg, 83\%). Mp 63-64 ${ }^{\circ} \mathrm{C} ;{ }^{1} \mathrm{H}-\mathrm{NMR}(500 \mathrm{MHz}$, $\mathrm{CDCl}_{3}$ ): $\delta 9.07$ (br s, $\left.1 \mathrm{H}\right), 4.66(\mathrm{q}, J=7.1 \mathrm{~Hz}, 2 \mathrm{H}), 2.37$ (q, $J=$ $7.6 \mathrm{~Hz}, 2 \mathrm{H}), 2.26(\mathrm{~s}, 3 \mathrm{H}), 2.21(\mathrm{~s}, 3 \mathrm{H}), 1.46(\mathrm{t}, J=7.1 \mathrm{~Hz}, 3 \mathrm{H}), 1.04$ $(\mathrm{t}, J=7.6 \mathrm{~Hz}, 3 \mathrm{H}) ;{ }^{13} \mathrm{C}-\mathrm{NMR}\left\{{ }^{1} \mathrm{H}\right\}\left(125 \mathrm{MHz}, \mathrm{CDCl}_{3}\right): \delta$ 199.5, 134.2, 128.7, 125.9, 122.1, 66.5, 17.2, 15.3, 14.3, 12.0, 11.8; HRMS-ESI $(m / z):[\mathrm{M}+\mathrm{Na}]^{+}$calculated for $\mathrm{C}_{11} \mathrm{H}_{17} \mathrm{NOSNa}$, 234.0923; found 234.0914.

Method 2. $1 \mathrm{M} \mathrm{BH}_{3} \cdot \mathrm{THF}(1.9 \mathrm{~mL}, 1.9 \mathrm{mmol})$ was added dropwise to a solution of $1 \mathrm{e}(569 \mathrm{mg}, 2.52 \mathrm{mmol})$ in THF $(18 \mathrm{~mL})$ at $0{ }^{\circ} \mathrm{C}$, under nitrogen. The reaction mixture was stirred for 18 hours, then quenched by slowly adding distilled water $(2 \mathrm{~mL})$, $5 \%$ aq. $\mathrm{HCl}(10 \mathrm{~mL})$, and stirring for a further 30 minutes at room temperature. Saturated $\mathrm{NaCl}(10 \mathrm{~mL})$ was added, and the resulting mixture was extracted into EtOAc $(3 \times 10 \mathrm{~mL})$. The combined organic fractions were washed with saturadted $\mathrm{NaHCO}_{3}(10 \mathrm{~mL})$ and brine $(10 \mathrm{~mL})$, dried over anhydrous $\mathrm{Na}_{2} \mathrm{SO}_{4}$ and concentrated in vacuo. The crude mixture was purified via column chromatography on silica, eluting with $3 \%$ EtOAc/hexanes to afford the desired product as a crystalline yellow solid (325 mg, 61\%). Characterisation data matched that provided above.

\section{1,3,7,9-Tetramethyl-2,8-diethyl-5- $\mathrm{H}$-4,6-dipyrrin hydrobromide (7)}

Pyrrole 1c (64 mg, $0.3 \mathrm{mmol}$ ) was added to formic acid $(0.29 \mathrm{~mL})$ and the resulting mixture heated to reflux temperature before $\mathrm{HBr}(0.096 \mathrm{~mL}, 0.84 \mathrm{mmol})$ was added. The reaction mixture was stirred for an hour at reflux temperature. Then, the mixture was allowed to cool down to room temperature and was kept in the fridge for 2 days. The precipitate was collected and washed with ether to obtain a red-orange solid (49 mg, 49\%). ${ }^{1} \mathrm{H}-\mathrm{NMR}$ (300 MHz, $\left.\mathrm{CDCl}_{3}\right): \delta 12.92($ br s, 2H), $7.02(\mathrm{~s}, 1 \mathrm{H}), 2.66(\mathrm{~s}, 6 \mathrm{H})$, $2.42(\mathrm{q}, J=7.6 \mathrm{~Hz}, 4 \mathrm{H}), 2.26(\mathrm{~s}, 6 \mathrm{H}), 1.07(\mathrm{t}, J=7.6 \mathrm{~Hz}, 6 \mathrm{H})$, in accordance with literature. ${ }^{42}$

\section{O-Ethyl 3,5-dimethyl-1H-pyrrole-2-carbothioate (1a) from 1e}

The title compound was synthesised following a modified literature procedure. ${ }^{43}$ Ethylene glycol $(1.5 \mathrm{~mL})$, para-toluene sulfonic acid (16 mg, $0.08 \mathrm{mmol})$ and 1e (174 $\mathrm{mg}, 0.77 \mathrm{mmol})$ were added to a $2 \mathrm{~mL}$ microwave vial equipped with a stir bar. The vial was sealed and the mixture was pre-stirred for 1 minute then heated for 2 minutes at $100{ }^{\circ} \mathrm{C}$ in a laboratory microwave. Once allowed to cool to room temperature, the vial was unsealed. Water $(5 \mathrm{~mL})$ was added and the mixture was extracted into $\mathrm{CH}_{2} \mathrm{Cl}_{2}(3 \times 5 \mathrm{~mL})$. The combined organic fractions were dried over anhydrous $\mathrm{Na}_{2} \mathrm{SO}_{4}$ and then concentrated in vacuo. The crude mixture was purified via column chromatography on silica, eluting with 5\% EtOAc/hexanes to yield the desired product as a yellow solid (95 mg, 67\%). ${ }^{1} \mathrm{H}-\mathrm{NMR}(300$ $\mathrm{MHz} \mathrm{CDCl}_{3}$ ): $\delta 9.09$ (br s, $\left.1 \mathrm{H}\right), 5.85(\mathrm{~s}, 1 \mathrm{H}), 4.65(\mathrm{q}, J=7.1 \mathrm{~Hz}$, $2 \mathrm{H}), 2.30(\mathrm{~s}, 3 \mathrm{H}), 2.25(\mathrm{~s}, 3 \mathrm{H}), 1.46(\mathrm{t}, J=7.1 \mathrm{~Hz}, 3 \mathrm{H})$, in accordance with literature. ${ }^{9}$

\section{Potassium $O$-benzyl carbonodithioate}

The title compound was synthesised following a modified literature procedure. ${ }^{25}$ Carbon disulfide $(17.4 \mathrm{~mL}, 289 \mathrm{mmol})$ and benzyl alcohol (25 mL, $242 \mathrm{mmol})$ were added to a suspension of $\mathrm{KOH}(13.5 \mathrm{~g}, 242 \mathrm{mmol})$ in diethyl ether (375 $\mathrm{mL}$ ). The suspension was stirred at room temperature for 3 hours. The product was collected via suction filtration and washed with $\mathrm{Et}_{2} \mathrm{O}$ to yield the desired product as a pale yellow solid (34.3 g, 64\%). ${ }^{1} \mathrm{H}-\mathrm{NMR}$ (300 MHz, DMSO-d ${ }_{6}$ ): $\delta$ 7.35-7.27 $(\mathrm{m}, 5 \mathrm{H}), 5.33(\mathrm{~s}, 2 \mathrm{H})$, in accordance with literature. ${ }^{35}$

\section{$O$-Benzyl acetothioacetate}

The title compound was synthesised following a modified literature procedure. ${ }^{39}$ A solution of chloroacetone $(5.4 \mathrm{~mL}, 67.4 \mathrm{mmol})$ in acetone $(34 \mathrm{~mL})$ was added drop-wise to a solution of potassium $O$-benzyl carbonodithioate in acetone $(84 \mathrm{~mL})$ at $0{ }^{\circ} \mathrm{C}$ over a period 
of 10 minutes with stirring. After 1 hour, the solvent was removed in vacuo. The resulting mixture containing $S$-acetonyl $O$-benzyl dithiocarbonate was dissolved in $\operatorname{dry~}^{2} \mathrm{Et}_{2} \mathrm{O}(27 \mathrm{~mL})$ and was added drop-wise over 20 minutes to a suspension of $\mathrm{NaH}(60 \%$ in oil, $3.2 \mathrm{~g}, 81.0 \mathrm{mmol})$ in dry $\mathrm{Et}_{2} \mathrm{O}(135 \mathrm{~mL})$ under nitrogen at $10{ }^{\circ} \mathrm{C}$. After 10 minutes, the reaction mixture was poured into aqueous $\mathrm{KH}_{2} \mathrm{PO}_{4}$ solution $(1.2 \mathrm{M}, 200 \mathrm{~mL})$ and stirred at room temperature. The ethereal layer was separated and the aqueous layer was extracted with ether $(3 \times 100 \mathrm{~mL})$. The combined organic fractions were washed with brine $(150 \mathrm{~mL})$, dried with anhydrous $\mathrm{MgSO}_{4}$ and concentrated in vacuo. The resulting residue was purified via column chromatography on silica, eluting with $2 \%$ ethyl acetate/ hexanes to isolate the desired product as a yellow liquid (1.9 g, $13 \%)$. The product was isolated as a mixture containing enol and keto forms with an approximate $3: 1$ enol-keto ratio according to the ${ }^{1} \mathrm{H}$ NMR spectrum. ${ }^{1} \mathrm{H}-\mathrm{NMR}\left(500 \mathrm{MHz}, \mathrm{CDCl}_{3}\right): \delta 13.70(\mathrm{~s}, 1 \mathrm{H})$, 7.40-7.35 (m, 6.9H), $5.76(\mathrm{~s}, 1 \mathrm{H}), 5.51(\mathrm{~s}, 0.7 \mathrm{H}), 5.46(\mathrm{~s}, 2 \mathrm{H}), 3.95(\mathrm{~s}$, 0.7H), 2.24 (s, 1H), $2.04(\mathrm{~s}, 3 \mathrm{H}) ;{ }^{13} \mathrm{C}-\mathrm{NMR}\left\{{ }^{1} \mathrm{H}\right\}\left(125 \mathrm{MHz}, \mathrm{CDCl}_{3}\right)$ : $\delta$ 213.1, 208.1, 177.8, 135.4, 134.7, 128.9, 128.8, 128.75, 128.72, 128.6, 128.5, 103.3, 74.7, 70.9, 61.7, 31.1, 29.9, 23.3; HRMS-ESI ( $\mathrm{m} /$ $z):[\mathrm{M}+\mathrm{Na}]^{+}$calculated for $\mathrm{C}_{11} \mathrm{H}_{12} \mathrm{O}_{2} \mathrm{SNa}, 231.0450$; found 231.0460 .

\section{O-Benzyl 4-acetyl-3,5-dimethyl-1H-pyrrole-2-carbothioate}

The title compound was synthesised following a modified literature procedure. ${ }^{41}$ A solution of $\mathrm{NaNO}_{2}(235 \mathrm{mg}, 3.41 \mathrm{mmol})$ in distilled water $(852 \mu \mathrm{L})$ was added drop-wise to a solution of $O$-benzyl acetothioacetate $(645 \mathrm{mg}, 3.10 \mathrm{mmol}$ ) in AcOH (774 $\mu \mathrm{L})$ at $0{ }^{\circ} \mathrm{C}$. The reaction mixture was stirred at room temperature and monitored via thin layer chromatography until the starting material was consumed. The reaction mixture was then transferred to a dropping funnel and added drop-wise to a slurry of 2,4-pentanedione $(316 \mu \mathrm{L}, 3.10 \mathrm{mmol}), \mathrm{Na}_{2} \mathrm{CO}_{3}$ (361 $\mathrm{mg}, 3.41 \mathrm{mmol}$ ) and $\mathrm{AcOH}(2 \mathrm{~mL})$. At the same time, $\mathrm{Zn}$ dust (11.4 g, $173.9 \mathrm{mmol}$ ) was slowly added to the slurry with the rate of addition and an ice-bath was used to keep the temperature below $30{ }^{\circ} \mathrm{C}$. After full addition, the reaction mixture was stirred at room temperature. The resulting mixture was poured into distilled water $(25 \mathrm{~mL})$ and then filtered through Celite, washing with $\mathrm{CH}_{2} \mathrm{Cl}_{2}$. The filtrate was extracted with $\mathrm{CH}_{2} \mathrm{Cl}_{2}$ (3 $\times 10 \mathrm{~mL}$ ). The combined organic fractions were washed with saturated $\mathrm{NaHCO}_{3}(10 \mathrm{~mL})$ and brine $(10 \mathrm{~mL})$, then dried over anhydrous $\mathrm{Na}_{2} \mathrm{SO}_{4}$ and evaporated in vacuo. The resulting residue was purified via column chromatography on silica, eluting with a gradient of 5-20\% ethyl acetate/hexanes, then washed with pentane $(3 \times 25 \mathrm{~mL})$, yielding the desired product as a yellow solid (168 mg, 19\%). Mp 122-124 ${ }^{\circ} \mathrm{C} ;{ }^{1} \mathrm{H}-\mathrm{NMR}(500$ $\mathrm{MHz}, \mathrm{CDCl}_{3}$ ): $\delta 9.43$ (br s, $\left.1 \mathrm{H}\right), 7.45-7.36(\mathrm{~m}, 5 \mathrm{H}), 5.68(\mathrm{~s}, 2 \mathrm{H})$, $2.54(\mathrm{~s}, 3 \mathrm{H}), 2.51(\mathrm{~s}, 3 \mathrm{H}), 2.43(\mathrm{~s}, 3 \mathrm{H}) ;{ }^{13} \mathrm{C}-\mathrm{NMR}\left\{{ }^{1} \mathrm{H}\right\} \mathrm{NMR}(125$ $\left.\mathrm{MHz}, \mathrm{CDCl}_{3}\right): \delta 200.7,195.9,141.0,135.4,128.8,128.62,128.58$, 128.56, 127.1 125.0, 73.1, 31.6, 15.5, 14.0; HRMS-ESI $(\mathrm{m} / \mathrm{z}):[\mathrm{M}+$ $\mathrm{Na}]^{+}$calculated for $\mathrm{C}_{16} \mathrm{H}_{17} \mathrm{NO}_{2} \mathrm{SNa}, 310.0872$; found 310.0869 .

\section{Conflicts of interest}

The authors declare no competing financial interest.

\section{Acknowledgements}

This work was supported by the Natural Sciences and Engineering Research Council of Canada (NSERC) courtesy of a Discovery Grant (AT) and the CREATE Training Program in BioActives (510963). NSERC (MJK, MHRB), Nova Scotia Graduate (MJK, MHRB) and Laing Undergraduate Research Award (SMG) scholarships are acknowledged.

\section{References}

1 J. M. Wood, D. P. Furkert and M. A. Brimble, Nat. Prod. Rep., 2019, 36, 289-306.

2 L. Knorr, Justus Liebigs Ann. Chem., 1886, 236, 290-314.

3 J. B. Paine III and D. Dolphin, J. Org. Chem., 1985, 50, 55985604.

4 G. Anguera, W. Y. Cha, M. D. Moore, J. T. Brewster, M. Y. Zhao, V. D. Lynch, D. Kim and J. L. Sessler, Angew. Chem., Int. Ed., 2018, 57, 2575-2579.

5 S. Neya, T. Yoneda, H. Omori, T. Hoshino, A. T. Kawaguchi and M. Suzuki, Tetrahedron, 2017, 73, 6780-6785.

6 S. Shah, C. Lee, H. Choi, J. Gautam, H. Jang, G. J. Kim, Y.-J. Lee, C. L. Chaudhary, S. W. Park, T.-g. Nam, J.-A. Kim and B.-S. Jeong, Org. Biomol. Chem., 2016, 14, 4829-4841.

7 Y. Yang, S. Chen, L. Liu, S. Li, Q. Zeng, X. Zhao, H. Li, Z. Zhang, L.-S. Bouchard, M. Liu and X. Zhou, ACS Appl. Mater. Interfaces, 2017, 9, 23400-23408.

8 A. Tsotinis, P. A. Afroudakis, K. Davidson, A. Prashar and D. Sugden, J. Med. Chem., 2007, 50, 6436-6440.

9 B. R. Groves, D. A. Smithen, T. S. Cameron and A. Thompson, RSC Adv., 2016, 6, 69691-69697.

10 M. A. Shalaby and H. Rapoport, J. Org. Chem., 1999, 64, 10651070.

11 T. L. Cottrell, The strengths of chemical bonds, Butterworths Scientific Publications, London, England, 2nd edn, 1958.

12 A. El Gamal, V. Agarwal, S. Diethelm, I. Rahman, M. A. Schorn, J. M. Sneed, G. V. Louie, K. E. Whalen, T. J. Mincer, J. P. Noel, V. J. Paul and B. S. Moore, Proc. Natl. Acad. Sci. U. S. A., 2016, 113, 3797-3802.

13 C. T. Walsh, S. Garneau-Tsodikova and A. R. Howard-Jones, Nat. Prod. Rep., 2006, 23, 517-531.

14 T. M. Cresp and M. V. Sargent, J. Chem. Soc., Perkin Trans. 1, 1973, 2961-2971.

15 C. E. Loader and H. J. Anderson, Can. J. Chem., 1969, 46, 3879-3885.

16 B. Föhlisch, D. Abu Bakr and P. Fischer, J. Org. Chem., 2002, 67, 3682-3686.

17 C. Savarin, J. Srogl and L. S. Liebeskind, Org. Lett., 2000, 2, 3229-3231.

18 R. Mozingo, D. E. Wolf, S. A. Harris and K. Folkers, J. Am. Chem. Soc., 1943, 65, 1013-1016.

19 E. Bullock, T.-S. Chen and C. E. Loader, Can. J. Chem., 1966, 44, 1007-1011.

20 L. Birry and A. Lasia, J. Appl. Electrochem., 2004, 34, 735-749.

21 I. Pogorelić, M. Filipan-Litvić, S. Merkaš, G. Ljubić, I. Cepanec and M. Litvić, J. Mol. Catal. A: Chem., 2007, 274, 202-207. 
22 B. Klenke and I. H. Gilbert, J. Org. Chem., 2001, 66, 24802483.

23 X. Wang and R. Rinaldi, ChemSusChem, 2012, 5, 1455-1466.

24 J. M. Khurana and R. Arora, Synthesis, 2009, 1127-1130.

25 H. Hauptmann and W. F. Walter, Chem. Rev., 1962, 62, 347404.

26 J. Rentner, M. Kljajic, L. Offner and R. Breinbauer, Tetrahedron, 2014, 70, 8983-9027.

27 S. S. Bokatzian-Johnson, M. L. Maier, R. H. Bell, K. E. Alston, B. Y. Le and E. A. Cioffi, J. Labelled Compd. Radiopharm., 2007, 50, 380-383.

28 R. J. Heys, J. Labelled Compd. Radiopharm., 2010, 53, 716721.

29 G. R. Pettit and R. E. Kadunce, J. Org. Chem., 1962, 27, 45664570 .

30 A. Call, C. Casadevall, F. Acuna-Pares, A. Casitas and J. Lloret-Fillol, Chem. Sci., 2017, 8, 4669-5218.

31 W. Liu, L. Li and C.-J. Li, Nat. Commun., 2015, 6, 6526.

32 P. J. Wright and A. M. English, J. Am. Chem. Soc., 2003, 125, 8655-8665.
33 X. Zhang, H. Wang and Y. Guo, Rapid Commun. Mass Spectrom., 2006, 20, 1877-1882.

34 A. J. Bridges and G. H. Whitham, J. Chem. Soc., Perkin Trans. 1, 1975, 1603-1606.

35 F. Carta, A. Akdemir, A. Scozzafava, E. Masini and C. T. Supuran, J. Med. Chem., 2013, 56, 4691-4700.

36 L. Knorr, Ber. Dtsch. Chem. Ges., 1884, 17, 1635.

37 E. V. Antina, G. B. Guseva, A. E. Loginova, A. S. Semeikin and A. I. V'yugin, Russ. J. Gen. Chem., 2010, 80, 2374-2381.

38 H. Fischer, Org. Synth., 1935, 15, 17.

39 M. D. Brown, D. W. Gillon, G. D. Meakins and G. H. Whitham, J. Chem. Soc., Perkin Trans. 1, 1985, 16231626.

40 B. Groves, D. Smithen, S. Cameron and A. Thompson, RSC Adv., 2016, 6, 69691-69697.

41 S. Mula, A. K. Ray, M. Banerjee, T. Chaudhuri, K. Dasgupta and S. Chattopadhyay, J. Org. Chem., 2008, 73, 2146-2154.

42 T. E. Wood, B. Berno, C. S. Beshara and A. Thompson, J. Org. Chem., 2006, 71, 2964-2971.

43 J. Regourd, I. M. Comeau, C. S. Beshara and A. Thompson, J. Heterocycl. Chem., 2006, 43, 1709-1714. 